Article

\title{
Disinfection of Treated Wastewater and its Reuse in the Irrigation of Golf Grass: The Case of Plant M'zar Agadir-Morocco
}

\author{
Hind Mouhanni $^{1, *}$, Abelaziz Bendou ${ }^{2}$ and Salah Er-Raki ${ }^{3}$ \\ 1 Laboratoire d'Ingénierie d'Energie et d'Environnement, ENSA, Agadir, 80000, Morocco \\ 2 Ecole Nationale de Commerce et de Gestion, Agadir, 80000, Morocco; \\ E-Mail: aziz.bendou@gmail.com \\ 3 LP2E2M, Faculty of Sciences and Techniques, Cadi Ayyad University, Marrakech, 40000, \\ Morocco; E-Mail: s.erraki@gmail.com \\ * Author to whom correspondence should be addressed; E-Mail: hmouhanni@yahoo.fr; \\ Tel.:+212-668-797-969; Fax: +212-528-239-700.
}

Received: 15 July 2011; in revised form: 4 October 2011 / Accepted: 21 October 2011 / Published: 8 December 2011

\begin{abstract}
The treated wastewater of Agadir M'zar plant has a good physico-chemical quality and it contains important nutrients (NPK: nitrogen, phosphorus, potassium). However, the reuse of this water, without disinfecting it, for irrigating the golf grass in the Agadir region, revealed the presence of a bacterial load that can hinder the quality and suitability of spaces for a population that is very demanding. Among the various methods of water disinfection, chlorination with bleach is the least expensive and the most systematically simple. Its effectiveness depends only on the $\mathrm{pH}$ of the waters to be disinfected. This study reports the results of disinfection of M'zar plant wastewater with a solution of sodium hypochlorite (bleach), and their reuse for irrigating the golf grass. For this purpose, we carried out a monitoring protocol for germination and growth parameters (number of tillers and leaf length) in order to study and compare the effect of disinfected treated wastewater (DTWW) and groundwater (GW) on the plant turf. The obtained result showed that the disinfection with bleach increased the salinity of the treated wastewater and can affect the permeability of soils and crops.
\end{abstract}


Keywords: treated wastewater; disinfection; groundwater; irrigation; golf grass; germination; growth

\section{Introduction}

In many part of the world, wastewater reclamation and reuse have been an interesting alternative source of water for irrigation, and many researchers have confirmed its benefits. In Mediterranean countries, treated wastewater is exponentially used for irrigating ornamental plants in areas with water scarcity. It could be an economic way to decrease pollution of surface waters and provide groundwater recharge for other agricultural fields. In this context, many studies have focused on the disinfection of treated wastewater and reuse in irrigation through improving its bacteriological and chemical qualities. In Spain, Salgot et al. [1] studied wastewater reuse, and they concluded that the reclaimed wastewater can be reused for different applications depending on specific water quality categories. Biological and chemical parameters have to indicate all potential pathogens and chemical intoxications in relation to the origin of sewage. Therefore, it is necessary to find adequate indicators which can be performed by chemical as well as biological quantitative risk assessment. In Italy, Lubello et al. [2] have studied the irrigation of nursery ornamental plants with tertiary effluents (filtration and peracetic acid $+U V$ ) in comparison with nutrient enriched groundwater. They concluded that the refinery treatment by filtration and disinfection with peracetic acid and UV together were very effective in bacteria removal. It was able to maintain good plant growth as well as fertigated water for most of the tested species.

In our study, we dealt with the case of Agadir (south of Morocco: altitudes between 30 and $31^{\circ} \mathrm{N}$ ) (Figure 1). The region of Agadir is an agricultural region that is characterized by an arid climate, very limited water resources and poor nutrient soils. The agricultural sector is the largest consumer of water. Thus, the use of treated wastewater in agriculture is a good alternative that will help preserve water resources in the region. Moreover, given the nutritional wealth of the treated wastewater, this solution will permit a recycling of these items and reduce the abusive misuse of fertilizers [3].

Figure 1. Localization of the M'zar plant of Agadir.

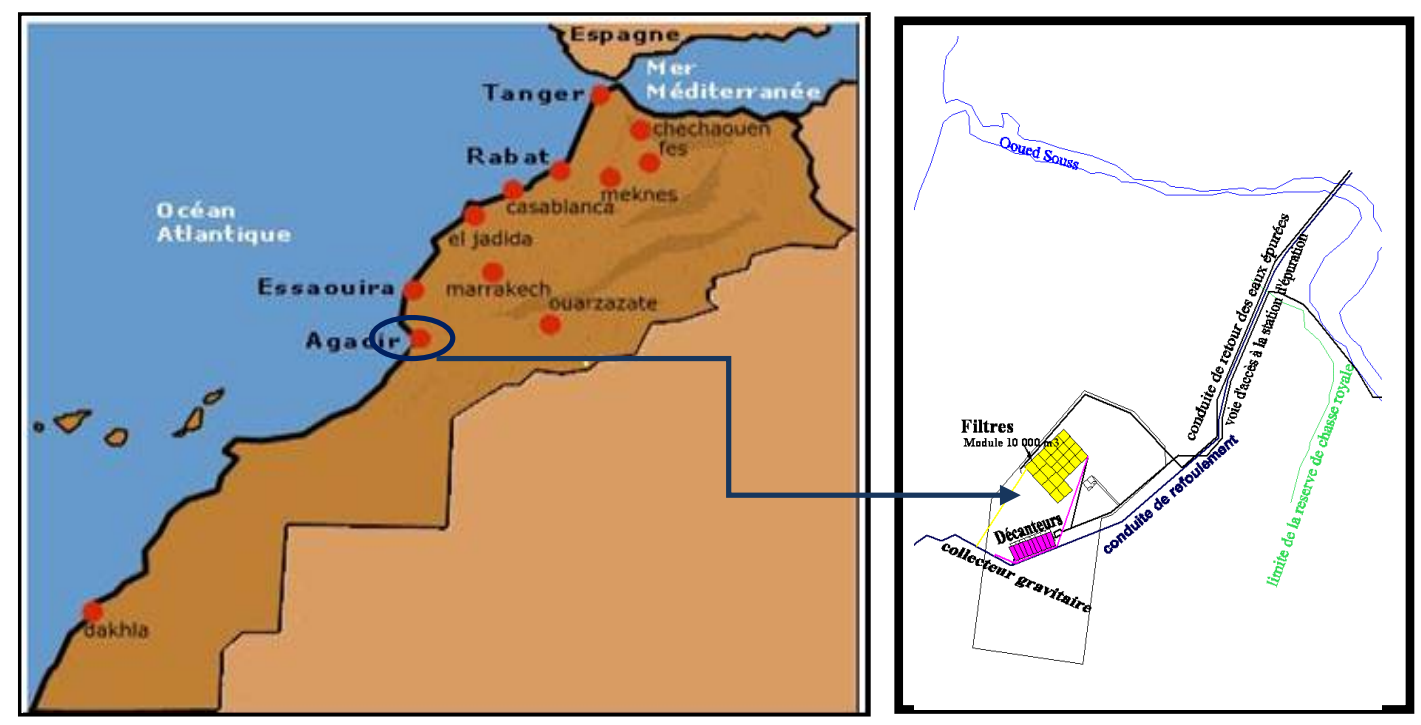


The current potential of wastewater treated by the Agadir M'zar plant, which might be used for unrestricted irrigation (category A WHO standards), is $10,000 \mathrm{~m}^{3} /$ day and will reach $50,000 \mathrm{~m}^{3} /$ day in the medium term. A feasibility study on the reuse of the Agadir M'zar plant wastewater was launched by RAMSA (Régie Autonome Multiservices d'Agadir; Water Supply Service of Agadir). In this context, the total surface of green spaces of Agadir city is estimated to be $878 \times 10^{4} \mathrm{~m}^{2}$ with a need of water for irrigation reaching $8,106 \mathrm{~m}^{3} /$ year. With a daily flow of $50,000 \mathrm{~m}^{3} /$ day, the treated wastewater of the M'zar plant will completely fill this need. The golf grass alone occupy $30.5 \%\left(268 \times 10^{4} \mathrm{~m}^{2}\right)$ of the total area of green space in Agadir $\left(878 \times 10^{4} \mathrm{~m}^{2}\right)$, with a water consumption estimated to be $3216,103 \mathrm{~m}^{3} /$ year [4,5]. This study focuses on disinfecting the treated wastewater to sodium hypochlorite for irrigating the golf courses' grass. It presents the planning, protocol and preliminary results of the tests that are carried out to evaluate the effects of the disinfected treated wastewater in the reuse for irrigating golf grass. Particular attention is given to the monitoring of the parameters of germination and growth of grass plants irrigated with disinfected treated wastewater compared to those irrigated by water from groundwater.

\section{Materials and Methods}

\subsection{Test Protocols of Disinfected Treated Wastewater Reuse}

In order to study the feasibility and assess the impact of the disinfected treated wastewater use on irrigation of golf grass, three varieties of turf golf courses V1 (Penccross), V2 (English Ray Gras) and V3 (red fescue mixed with English Ray Gras) were used on three plots (P1, P2, P3) for comparison. The same tests were reproduced under the same conditions using groundwater.

Each plot has a size of $25 \mathrm{~m}^{2}$ and is divided into two parcels of $12.5 \mathrm{~m}^{2}$ to ensure a repetition of the conditions of each test. The subdivision of each parcel is insured by placing a plastic insulator at a depth of $0.5 \mathrm{~m}$ to prevent infiltration between subdivisions. Each parcel contains a layer of $20 \mathrm{~cm}$ of soil composed with $75 \%$ topsoil and $25 \%$ sand and a lysimeter on two opposite corners. The lysimeters have a volume of $1 \mathrm{~m}^{3}$ and reproduce the conditions of soil and variety of grass planted in the parcel. These lysimeters are designed with a good seal for the recovery of the leachate after irrigation [4].

In order to determine the percentage of germination, the three varieties of golf grass (V1, V2, and V3) were sown into alveolars trays on the plant site. For each variety of turf, two trays with 56 alveolars are sown (one seed per alveolars). The soil used in the trays has the same composition as in the plots. The germination of seeds in the six trays is monitored for 41 days. Counting the seedlings starts from the emergence of the first plant (first day of growth) until 41 days for each variety. The irrigation of the plots and trays is ensured by the treated wastewater that underwent disinfection before each application. The frequency and volume of irrigation is similar to the testing of irrigation by treated wastewater and groundwater: three times a day and $90 \mathrm{~L} /$ day per $25 \mathrm{~m}^{2}$ plot.

\subsection{Soil Characteristics and Irrigation Water}

As mentioned above, soil plots are composed with $75 \%$ topsoil and $25 \%$ sand. Detailed soil analysis is presented in Table 1. From these results, the land has a loamy texture with little clay and some sand. It is slightly fitted with major nutrients and organic matter: total nitrogen, available phosphorus and 
exchangeable potash. In addition, the sands are very poor in any fertilizing element. The salinity of the two types of soil is very low. Otherwise the alkalinity of the sands is higher than that of the plant earth. Therefore soil cannot provoke any risk of damaging the cultures as it does not provide them with any nutriment. Therefore, the grass can only take advantage of fertilizing elements contained in waters or brought by possible amendments.

Table 1. Tests results of soil and sand.

\begin{tabular}{cccccccccc}
\hline Parameters & Texture & $\mathbf{p H}$ & $\begin{array}{c}\text { Organic } \\
\text { matter } \\
\mathbf{( \% )}\end{array}$ & $\begin{array}{c}\text { Total } \\
\text { nitrogen } \\
\mathbf{( \% )}\end{array}$ & $\begin{array}{c}\text { Total } \\
\text { Limestone } \\
\mathbf{( \% )}\end{array}$ & $\begin{array}{c}\mathbf{E C} \\
\mathbf{1 / 5} \\
(\mathbf{d S} / \mathbf{m})\end{array}$ & $\begin{array}{c}\text { Soluble } \\
\text { Salts } \\
(\mathbf{g} / \mathbf{k g})\end{array}$ & $\begin{array}{c}\mathbf{P}_{\mathbf{2}} \mathbf{O}_{\mathbf{5}} \\
\text { Assimilable } \\
(\mathbf{p p m})\end{array}$ & $\begin{array}{c}\mathbf{K}_{\mathbf{2}} \mathbf{O} \\
\text { Exchangeable } \\
(\mathbf{p p m})\end{array}$ \\
\hline Topsoil & LSC $^{*}$ & 8.70 & 1.85 & 0.15 & 5.20 & 0.12 & 0.41 & 14.56 & 128.70 \\
Sand & $\mathrm{S}$ & 9.6 & 0.05 & 0.01 & 36.7 & 0.045 & 0.16 & 1 & 24.9 \\
\hline
\end{tabular}

* LSC means loamy sandy clay.

The waters used for irrigation in experimental plots are of two main types:

- the groundwater of Souss plain, drawn from the well located in the wastewater plant zone;

- the treated wastewater of the plant M'zarAit Melloul, which uses the infiltration percolation process on bed sands and disinfected with bleach.

The main characteristics of treated wastewater before disinfection are shown in Table 2 . The assessment of water analysis of the groundwater and those treated allow their classification as irrigation water according to the USDA (U.S. Department of Agriculture). The USDA classification is based on the values of electrical conductivity (EC) and those of the index SAR (Sodium Adsorption Ratio) [6].

- The groundwaters are classified as $\mathrm{C} 2 \mathrm{~S} 1$, they can be used on any type of soil with minimal risk of sodium accumulation. Water salinity $(\mathrm{EC}=0.520 \mathrm{ds} / \mathrm{m})$ is close to the limit of turf growth without applying special treatments for salinity $(\mathrm{EC}$ limit located $=0.750 \mathrm{ds} / \mathrm{m}$ ).

- The treated wastewaters are classified as $\mathrm{C} 4 \mathrm{~S} 1$, they are very saline (EC at $25^{\circ} \mathrm{C}$ is of $3.15 \mathrm{ds} / \mathrm{m}$ ). However, they can be used for any type of soil as the value of the SAR is less than 10 .

Table 2. Results of ionic balance of treated wastewater before disinfecting and groundwater used for irrigation. (Please check)

\begin{tabular}{lcccc}
\hline & \multicolumn{2}{c}{ Groundwater } & \multicolumn{2}{c}{ Treated wastewater } \\
& $\mathbf{m g} / \mathbf{L}$ & $\left(\times \mathbf{1 0}^{-\mathbf{3}}\right) \mathbf{m o l e} / \mathbf{L}$ & $\mathbf{m g} / \mathbf{L}$ & $\left(\times \mathbf{1 0}^{-\mathbf{3}}\right) \mathbf{~ m o l e} / \mathbf{L}$ \\
\hline $\mathrm{pH}$ & \multicolumn{2}{c}{7.4} & \multicolumn{2}{c}{7.1} \\
$\mathrm{EC}$ at $25^{\circ} \mathrm{C} \mathrm{dS/m}$ & \multicolumn{2}{c}{0.58} & \multicolumn{2}{c}{3.15} \\
Sodium Adsorption Ratio (SAR) & \multicolumn{2}{c}{0.84} & 720 & 6.66 \\
\hline${\text { Chloride } \mathrm{Cl}^{-}}^{-128}$ & 3.61 & 43 & 20.31 \\
Potassium $\mathrm{K}^{+}$ & 2.89 & 0.07 & 487 & 1.1 \\
Sodium $\mathrm{Na}^{+}$ & 30.52 & 1.32 & 294.8 & 21.21 \\
${\text { Calcium } \mathrm{Ca}^{2+}}_{\text {Magnesium } \mathrm{Mg}^{2+}}$ & 47.8 & 1.19 & 65.9 & 7.35 \\
Total Nitrogen & 32.1 & 1.32 & 44.6 & 2.71 \\
\hline
\end{tabular}


Table 2. Cont.

\begin{tabular}{lcccc}
\hline & \multicolumn{2}{c}{ Groundwater } & \multicolumn{2}{c}{ Treated wastewater } \\
& $\mathbf{m g} / \mathbf{L}$ & $\left(\times \mathbf{1 0}^{-\mathbf{3}}\right) \mathbf{m o l e} / \mathbf{L}$ & $\mathbf{m g} / \mathbf{L}$ & $\left(\times \mathbf{1 0}^{-\mathbf{3}}\right) \mathbf{~ m o l e} / \mathbf{L}$ \\
\hline Phosphorus & 0.39 & 0.01 & 8.85 & 0.28 \\
Bicarbonate $\mathrm{HCO}_{3}{ }^{-}$ & 191 & 3.13 & 317 & 5.19 \\
Sulphate $^{4} \mathrm{SO}^{4-}$ & 10 & 0.1 & 85 & 0.88 \\
Nitrate $\mathrm{N}^{-} \mathrm{NO} 3$ & 5.2 & 0.08 & 350 & 5.64 \\
\hline
\end{tabular}

\section{Results and Discussion}

\subsection{Disinfection Tests Protocol}

Before applying the disinfected of the treated wastewater, we should first determine the chlorometric degree, Chlorine demand and break point for the bleach.

\subsubsection{Determination of the Chlorometric Degree}

The bleach solution is titrated with sodium thiosulfate $0.1 \mathrm{~N}$ and potassium iodide $10 \%$. The bleach used for disinfection of treated wastewater is titrated with a volume $(\mathrm{V}=69.2 \mathrm{~mL})$ of thiosulfate for a sample $(\mathrm{v}=10 \mathrm{~mL})$. Henceforth, the quantity of bleach is $24.56 \mathrm{Cl}_{2} \mathrm{~g} / \mathrm{L}$, so the bleach chlorometric degree is $7.74^{\circ} \mathrm{Cl}$.

\subsubsection{Chlorine Demand}

In order to determine the amount of chlorine that can be consumed by the water for its disinfection and destruction of organic matter, we followed the bacteriological analysis of the purified water throughout a week in order to select the maximum bacteriological load (Table 3). The samples are prepared in 10 numbered and corked bottles of $250 \mathrm{~mL}$. In each $100 \mathrm{~mL}$ of treated wastewater that were analyzed, increasing amounts of chlorine solutions $\left(0.1 \mathrm{~g} \mathrm{Cl}_{2} / \mathrm{L}\right)$ were introduced. The bottles were kept in the dark for 30 minutes at an ambient temperature of $20.6{ }^{\circ} \mathrm{C}$. Then, the residual chlorine was determined by the method of comparison in the range of the 10 bottles and $\mathrm{pH}$ as shown in Table 4 .

Table 3. Treated wastewater bacteriological load for disinfection tests.

\begin{tabular}{lcc}
\hline Designation & $\begin{array}{l}\text { Total Coliform (TC) } \\
\left(\mathbf{3 7}^{\circ} \mathbf{2 4} \mathbf{~ h}\right) \mathbf{U F C} / \mathbf{1 0 0} \mathbf{~ m L}\end{array}$ & $\begin{array}{l}\text { Feacal Coliforms (FC) } \\
\left(\mathbf{4 4} \mathbf{2 4}^{\circ} \mathbf{h}\right) \mathbf{U F C} / \mathbf{1 0 0} \mathbf{~ m L}\end{array}$ \\
\hline Stock solution $(\mathrm{SM})$ & $20 \times 10^{4}$ & $9 \times 10^{3}$ \\
\hline
\end{tabular}

Table 4. Range to determine the treated wastewater demand in chlorine

\begin{tabular}{lcccccccccc}
\hline Sample & $\mathbf{1}$ & $\mathbf{2}$ & $\mathbf{3}$ & $\mathbf{4}$ & $\mathbf{5}$ & $\mathbf{6}$ & $\mathbf{7}$ & $\mathbf{8}$ & $\mathbf{9}$ & $\mathbf{1 0}$ \\
\hline Volume of Chlorine Solution $(\mathrm{mL})$ & 5.2 & 11.1 & 25 & 42.8 & 66.6 & 81.8 & 150 & 233.3 & 400 & 900 \\
Active Concentration of $\mathrm{Cl}_{2}(\mathrm{mg} / \mathrm{L})$ & 5 & 10 & 20 & 30 & 40 & 45 & 60 & 70 & 80 & 90 \\
Residual Chlorine $\mathrm{mg} / \mathrm{L}$ & 1 & 6 & 10 & 20 & 50 & 60 & 40 & 30 & 20 & 70 \\
pH of Chlorine Solution & 8.09 & 8.13 & 8.06 & 7.90 & 7.91 & 7.77 & 7.87 & 7.97 & 8.38 & 8.73 \\
\hline
\end{tabular}




\subsubsection{Break Point Determination}

The break point is determined by the second concave curvature of the curve of the residual chlorine as a function of $\mathrm{Cl}_{2}$ concentration of the different concentrations (Figure 2). Therefore, here, the ninth bottle is the breaking point, where there is a concentration of $80 \mathrm{mg} / \mathrm{L}$ of active chlorine which corresponds to $30 \%$ of $\mathrm{HOCl}$ and $70 \%$ of $\mathrm{CLO}^{-}$a $\mathrm{pH}$ of 8.38 .

Figure 2. Disinfection break point determining curve of treated wastewater.

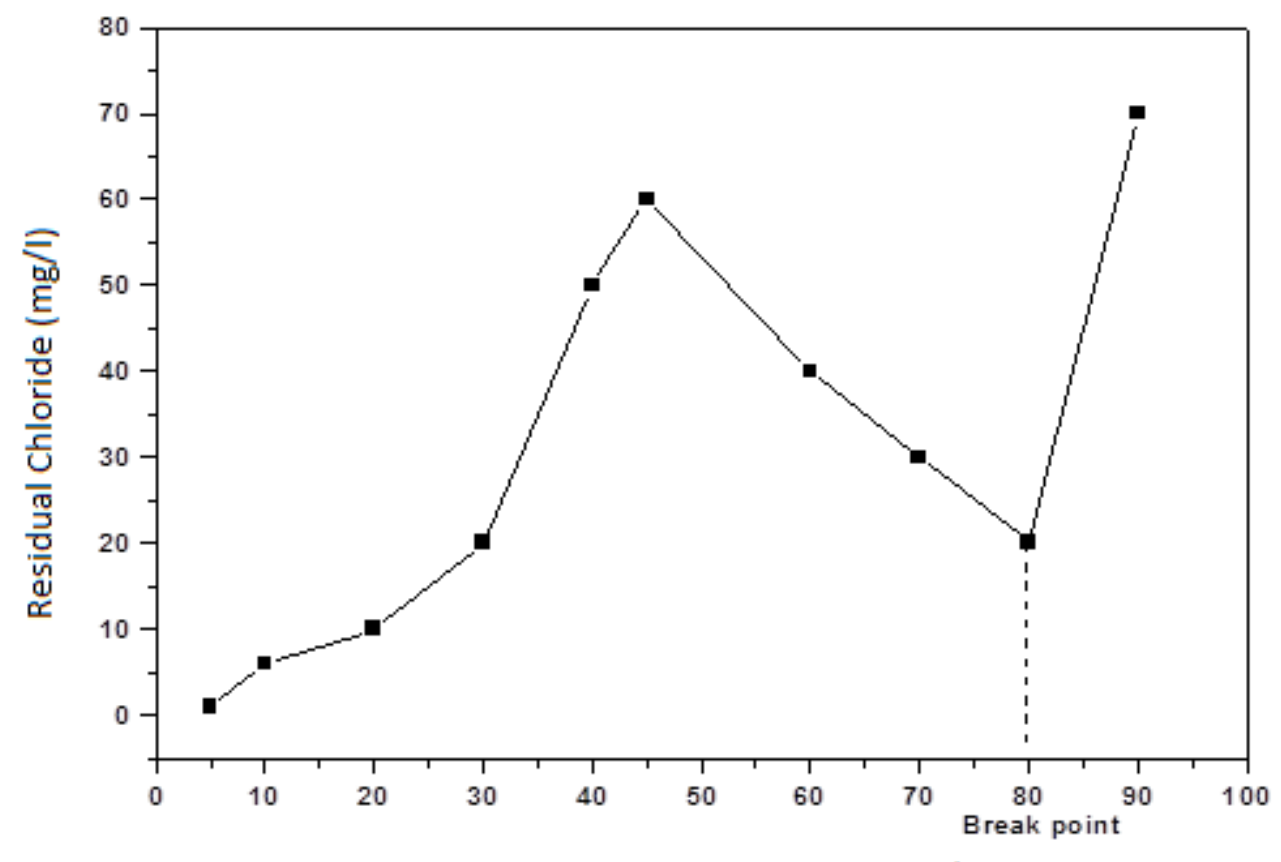

Injected concentration of $\mathrm{Cl}_{2}(\mathrm{mg} / \mathrm{l})$

\subsubsection{Bacteriological Tests Results}

In order to evaluate fecal pollution indicators before and after the break point of the treated wastewater, we have shown the water in the bottles 4, 9 and in the parent strain on the selective medium of total coliforms (TC) and fecal coliforms (FC). The results recorded on the plates after incubation are shown in Table 5.

Table 5. Results of the bacteriological tests of the disinfected treated wastewater.

\begin{tabular}{lcc}
\hline Designation & $\begin{array}{c}\text { Total Coliform (TC) } \\
\left(\mathbf{3 7 ^ { \circ }} \mathbf{2 4} \mathbf{~ h ) ~} \mathbf{U F C} / \mathbf{1 0 0} \mathbf{~ m L}\right.\end{array}$ & $\begin{array}{c}\text { Feacal Coliforms (FC) } \\
\left.\mathbf{( 4 4 ^ { \circ }} \mathbf{2 4 h}\right) \mathbf{U F C} / \mathbf{1 0 0} \mathbf{~ m L}\end{array}$ \\
\hline Stock solution (SM) & $20 \times 10^{4}$ & $9 \times 10^{3}$ \\
SM for dilution 10 & $9 \times 10^{4}$ & 0 \\
SM for dilution 10 & $10^{5}$ & 0 \\
4th bottle & $4 \times 10^{3}$ & 0 \\
4th bottle for dilution $10^{1}$ & 0 & 0 \\
4th bottle for dilution 10 & 0 & 0 \\
Break point (9th bottle) & 0 & 0 \\
\hline
\end{tabular}


We note an absence of fecal and total coliforms at the 9th bottle that matches the break point. This confirms the effect of disinfectant bleach to this concentration of chlorine $(80 \mathrm{mg} / \mathrm{L})$ for the treated wastewater of the M'zar plant. However, the disinfection by chlorination requires mastering many parameters ( $\mathrm{pH}$, temperature, turbidity, contact time, residual chlorine) that influence its effectiveness against the microorganisms.

\subsection{Growth Parameters}

The irrigation test results with disinfected treated wastewater and groundwater are presented in Figures 3, 4 and 5. These figures show the evolution of germination percentage, the number of tillers and leaf length for each variety of grass, respectively.

Figure 3. Evolution of the germination percentage of the different seed varieties irrigated with the two kinds of water: well water and disinfected treated wastewater.

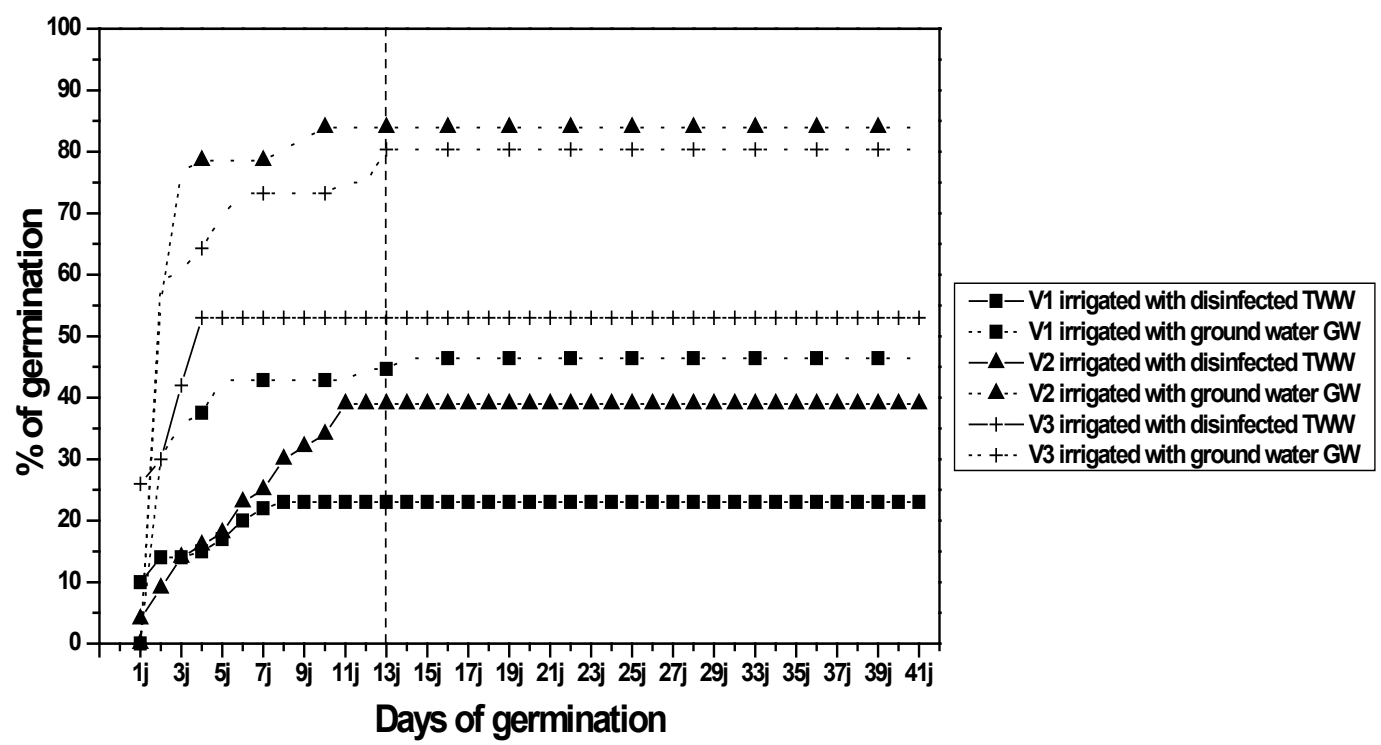

Figure 4. Evolution of the number of tillers in the irrigated plots with the two qualities of water: groundwater and disinfected treated wastewater.

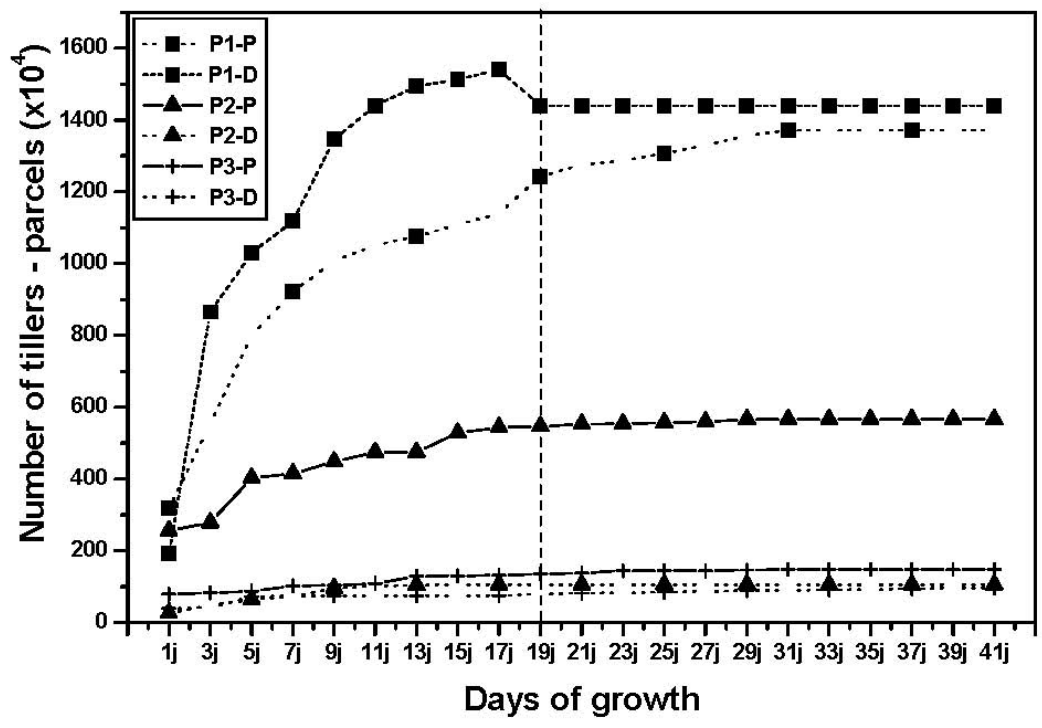

Pi-P : plots irrigated with groundwater ( $G W$ ) and enclosed the varietiei Pi-D : plots irrigated withdisinfected treated wastewater (DTWW and enclosed the varietie $i$ 
Figure 5. Evolution of the length of leaves in the irrigated plots with the two qualities of water: groundwater and disinfected treated wastewater.

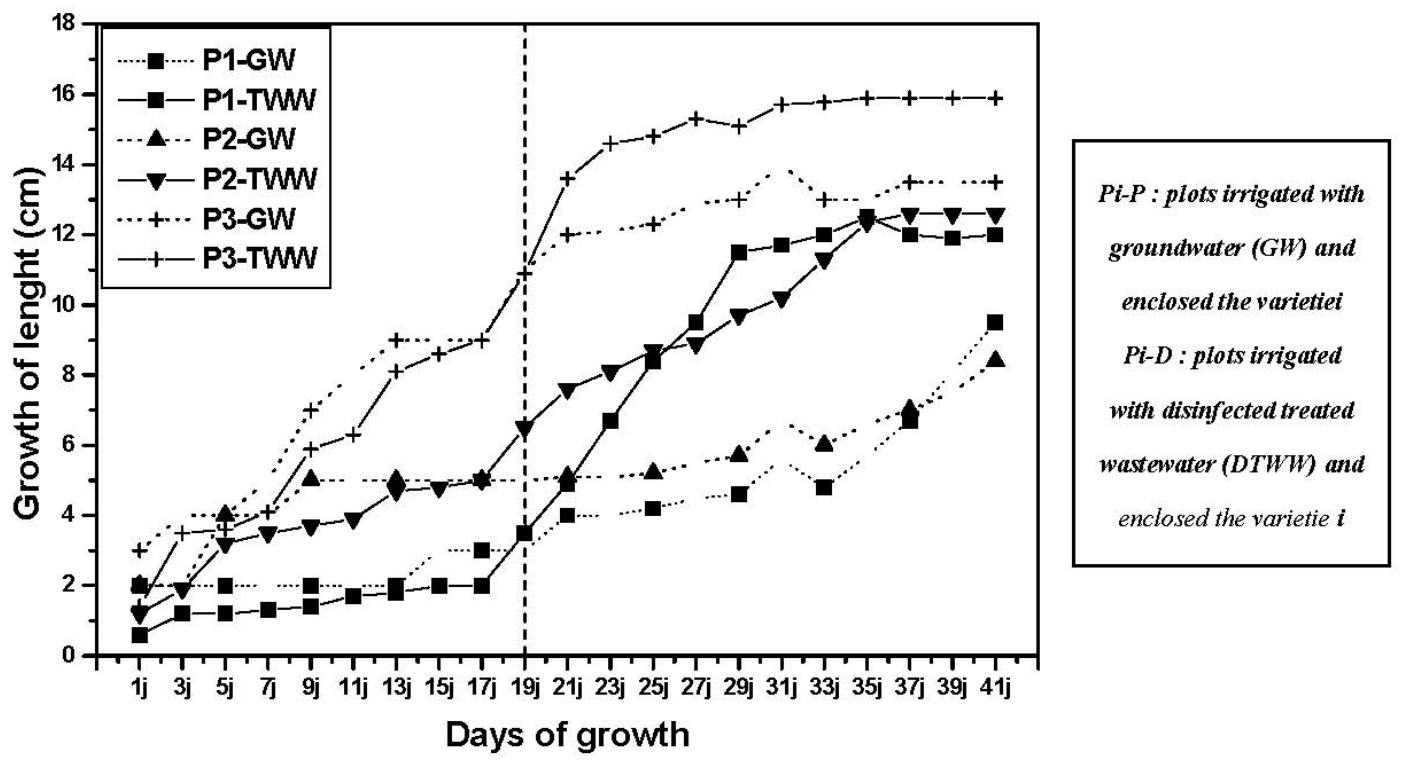

The evolution of the germination percentage shows that the germinating variety V1, V2 and V3 is favored by groundwater until the 13th day. Otherwise, the germination of these varieties is delayed by the salts in solution-treated wastewater that was disinfected during this phase. The salts caused the reported increase in the osmotic pressure of soil solution which has prevented the seed absorption and subsequently a poor port and then a reduction in performance [3,7-9].

After the 13th day, the germination percentage remained stable and reached a maximum of 23, 39 and $53 \%$ for varieties V1, V2 and V3, respectively. However, the maximum percentage of these varieties is doubled when they are irrigated with groundwater (46, 84 and $80 \%$ respectively) and similarly with treated wastewater $(50,79$ and $88 \%$ respectively).

Thus, the irrigation with disinfected treated wastewater has led to a reduction in the maximum germination percentage that reached more than $50 \%$ for all varieties compared to irrigation with groundwater.

Regarding the evolution of the number of tillers (Figure 4), we note that their increase before the maximum rate of germination reached is due to the contribution of the phenomenon of germination and tillering. The germination is reached after 13 days of sowing which is the 19th day of growth because we have a germination time of six days. The increased number of tillers after the 19th day of growth is limited to the phenomenon of tillering [10,11].

The irrigation using groundwater promotes tillering for the varieties V2 and V3 throughout the monitoring period. Variety V1 is the only one that has a better adaptation to the quality of disinfected treated wastewater which promotes tillering compared with groundwater. The observed variation compared to irrigation with disinfected treated wastewater is reduced only for varieties V1 and V3 after the 19th day of growth. Following this trend, we can conclude that tillering is stimulated by irrigation with groundwater, the treated wastewater and the disinfected treated wastewater in descending order. 
In order to monitor the growth of the aerial part of plant grass, a leaf sample is taken every two days. The average leaf length of each sample is measured on graph paper. The evolution of this length for different varieties irrigated by the two water qualities over 41 days is shown in Figure 5.

Before the maximum germination rate is reached (before the 19th day of growth, shown in Figure 3), we cannot observe the effect of irrigation with disinfected treated wastewater on the evolution of the leaf length. However, after the 19th day of growth, it is obviously the case that the irrigation by disinfected treated wastewater promotes the increased leaf length compared to the irrigation with groundwater for all varieties.

Irrigation by the disinfected treated wastewater affects the germination percentage and the tillering phenomenon of the leaf length. This is due to the concentration of sodium and chloride ions which influence the turf plant growth according to whether or not it is resistant to salinity. These results are consistent with [4,5] in which it is reported that the variety Ray Grass English accumulates more $\mathrm{Na}^{+}$ and $\mathrm{Cl}^{-}$in leaves than in roots, whereas, according to [12,13], it is classified as a species that is moderately sensitive to salinity.

\subsection{Microbiological Parameters}

At the end of the monitoring, samples of the aerial part of three varieties of turf were collected in plots and irrigated with groundwater and with disinfected treated wastewater for microbiological tests. These tests involve only the enumeration of Faecal Coliforms (FC) and Faecal Streptococci (FS) which are signs of germs and fecal contamination [14,15].

The bacteriological tests of the treated wastewater before disinfection are of about $1.32 \times 10^{4}$, $7.06 \times 10^{4}$ and $4.29 \times 10^{3} \mathrm{CFU} / 100 \mathrm{~mL}$, which are the annual average respectively for FC, TC and FS. The tests of the turf irrigated by these waters gave results that varied between $(190,000$ and 590,000 CFU/g) and (160 and $510 \mathrm{CFU} / \mathrm{g}$ ) respectively for CT and CF such as SF, which varies between 100 and $500 \mathrm{CFU} / \mathrm{gr}$. Salmonella is absent for all varieties irrigated by treated wastewater (Table 6). These values are close to those of the turf irrigated with well water which shows no Faecal contamination. CF, CT, FS and Salmonella were absent in $25 \mathrm{~g}$.

Table 6. Bacteriological tests of irrigated golf grass by treated wastewater and the groundwater at the end of 41 days and a turf irrigated by groundwater of an outer golf course.

\begin{tabular}{|c|c|c|c|c|c|}
\hline & \multicolumn{3}{|c|}{ Grass irrigated by TWW } & \multirow{2}{*}{$\begin{array}{c}\text { Grass irrigated } \\
\text { by GW } \\
\end{array}$} & \multirow{2}{*}{$\begin{array}{l}\text { Outer golf Grass } \\
\text { irrigated by GW }\end{array}$} \\
\hline & EV1 & EV2 & EV3 & & \\
\hline Total Coliforms (UFC/gr) & $1.90 \mathrm{E}+05$ & $2.20 \mathrm{E}+05$ & $5.90 \mathrm{E}+05$ & $3.80 \mathrm{E}+04$ & $1.00 \mathrm{E}+03$ \\
\hline Faecal Coliforms UFC/gr & $2.10 \mathrm{E}+02$ & $1.60 \mathrm{E}+02$ & $5.10 \mathrm{E}+02$ & $5.00 \mathrm{E}+02$ & $1.00 \mathrm{E}+03$ \\
\hline Faecal Streptococcus UFC/gr & $1.2 \mathrm{E}+02$ & $2.00 \mathrm{E}+02$ & $5.00 \mathrm{E}+02$ & $2.20 \mathrm{E}+02$ & $1.00 \mathrm{E}+02$ \\
\hline Salmonella UFC/25 gr & 0 & 0 & 0 & 0 & 0 \\
\hline
\end{tabular}

These results lead us to decide that the grass plant has had an external contamination originating from environmental pollution. Moreover, the treatment plant is installed in a reserve, and the plots of turf are installed in the next plant close to the sand filters and stock sludge. Therefore, we cannot exclude the possibility of an accidental contamination by the movement of wind, animal activity or the trampling of workers in the processing of the grass. 
In order to confirm this hypothesis, tests of a sample turf taken from the outer golf course is approximately $10^{3} \mathrm{CFU} / \mathrm{g}, 10^{2} \mathrm{CFU} / \mathrm{g}$ for CF, TB and SF, with an absence of Salmonella. These results confirm the results obtained from the irrigated grass by disinfected treated wastewater which has a concentration of CT between $8.2 \times 10^{4}$ and $4.3 \times 10^{5} \mathrm{CFU} / \mathrm{g}$. However, CF and anaerobic sulfite-reducers are below than $10 \mathrm{CFU} / \mathrm{g}$ as well as Salmonella that are absent in 25 grams, but the aerobic microorganisms are greater than $3 \times 10^{7} \mathrm{CFU} / \mathrm{g}$ (Table 7). This is consistent with the results of [8] in which it was announced that lettuce plants irrigated with the treated wastewater are more altered toward the end of the harvest than plants irrigated with fertilized water. This alteration may be due to the abundance of total mesophilic aerobic bacteria $\left(5.1 \times 10^{5} \mathrm{CFU} / \mathrm{g}\right)$ as the lettuce grows at ground level and can be easily contaminated by the bacterial group. Therefore, we can conclude that the disinfection has been successful from a microbiological point of view. However, it affects the germination and growth of turf plants by their intake of sodium and chloride ions, which increases the salinity of the treated wastewater.

Table 7. Bacteriological tests of irrigated golf grass by disinfected treated wastewater at the end of the monitored 41 days.

\begin{tabular}{lccc}
\hline & \multicolumn{3}{c}{ Irrigated grass by disinfected TWW } \\
& EV1 & EV2 & EV3 \\
\hline Total Coliforms (UFC/gr) & $4.3 \mathrm{E}+05$ & $8.2 \mathrm{E}+04$ & $3.2 \mathrm{E}+05$ \\
Faecal Coliforms UFC/gr & $<10$ & $<10$ & $<10$ \\
Faecal Streptococcus $\mathrm{UFC} / \mathrm{gr}$ & $<100$ & $<100$ & $<100$ \\
Anaerobic Sulfite-Reduction UFC/gr & $<10$ & $<10$ & $<10$ \\
AerobicMicroorganism at $30^{\circ} \mathrm{C}$ UFC/gr & $>3.107$ & $>3.107$ & $>3.107$ \\
Salmonella UFC/25 gr & 0 & 0 & 0 \\
\hline
\end{tabular}

\section{Conclusions}

The bacteriological tests of the irrigated turf by treated wastewater showed that concentrations of faecal and total coliforms and faecal streptococci are very high, while there is an absence of salmonella. Thus, the disinfection of these waters was prompted primarily by the sodium hypochlorite which gave satisfactory results in the treated waters and that has marked an absence of faecal contamination.

In general, the disinfection of sodium hypochlorite increased the salinity of the treated wastewater. As a result, these waters are suitable for irrigation only under some conditions: good soil leaching, salt-tolerant plant and highly permeable soils. As a result, care must be taken first in the management of irrigation doses to prevent accumulation of salts in the root zone and then in controlling their transfer into the waters of the aquifer.

\section{References}

1. Salgot, M.; Huertas, E.; Weber, S.; Dott, W.; Hollender, J. Wastewater reuse and risk: Definition of key objectives. Desalination 2006, 187, 29-40. 
2. Lubello, C.; Francesco, R.; Nicese, P.; Ferrini, F. Municipal-treated wastewater reuse for plant nurseries irrigation. Water Res. 2004, 38, 2939-2947.

3. Tomas, C. Water reuse of South Barcelona's wastewater reclamation plant. Desalination 2008, 218, 43-51.

4. Mouhanni, H.; Hamdi, H.; Bendou, A.; Benzine, L. Réutilisation des eaux usées épurées pour l'irrigation du gazon des golfs: Impact sur la germination et la croissance du gazon. Int. d'héliotech.-Energie-Environn. 2008, 38, 27-33.

5. Vuokko, O.K.; Tapio, S.; Pekka, E.P. Bilateral collaboration in municipal water and wastewater services in Finland. Water 2010, 2, 815-825.

6. Ayers, R.S.; Westcot, D. La qualité de l'eau en agriculture; Bulletin FAO d'irrigation et du drainage $\mathrm{N}^{\circ} 29$; FAO : Rome, Italy, 1976.

7. Salgot, M. Water reclamation, recycling and reuse: Implantation issues. Desalination 2008, 218 , 190-197.

8. Gros, A. Engrais: Guide Pratique de la Fertilisation, 3rd ed.; la maison rustique: Paris, France, 1997.

9. Zalesny, J.A.; Zalesny, R.S., Jr.; Wiese, A.H.; Sexton, B.; Hall, R.B. Sodium and chloride accumulation in leaf, woody, and root tissue of populus after irrigation with landfill leachate. Environ. Pollut. 2008, 155, 72-80.

10. Lucila, C.; Fabregat, S.; Josa, A.; Suriol, J.; Vigues, N.; Mas, J. Assessment of soil and groundwater impacts by treated urban wastewater reuse. A case study: Application in a golf course (Girona, Spain). Sci. Total Environ. 2007, 374, 26-35.

11. Mimouni, R. Etude Microbiologique des Eaux Usées Dans le Grand Agadir: Epuration par Infiltration-Percolation, Impact sur L'environnement Marin et Réutilisation en Agriculture; Thèse d'état, Université de Nancy: Nancy, France, 2004.

12. Lemaire, G.; Nicolardot, B. Maîtrise de l'azote dans les agrosystèmes; Editions INRA: Reims, France, 1997.

13. Rosenthal, R.; Vinokurov, E.; Ronen, A.; Magaritz, D.; Moshkovitz, M. Anthropogenically induced salinization of groundwater: A case study from the Coastal Plain aquifer of Israel. Hydrology 1992, 11, 149-171.

14. Benyakhlef, S. Impact de certaines pratiques culturales (irrigation par les eaux usées épurées et la fumigation) sur la microflore $d u$ sol; Thèse du troisième cycle, Université IbnouZohr: Agadir, Morocco, 1998.

15. Pollice, A.; Lopez, A.; Laera, G.; Rubino, P.; Lonigro, A. Tertiary filtered municipal wastewater as alternative water source in agriculture. Sci. Total Environ. 2004, 324, 201-210.

(C) 2011 by the authors; licensee MDPI, Basel, Switzerland. This article is an open access article distributed under the terms and conditions of the Creative Commons Attribution license (http://creativecommons.org/licenses/by/3.0/). 